\title{
International Journal of
}

\section{Image, Graphics \\ and Signal Processing}

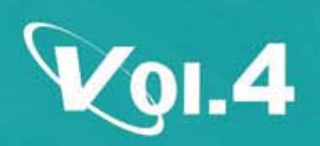

No. 5 Jun. 2012

IJIGSP KoI.4 Http:// www.mecs-press .org Vol. 4 No.5 June 2012

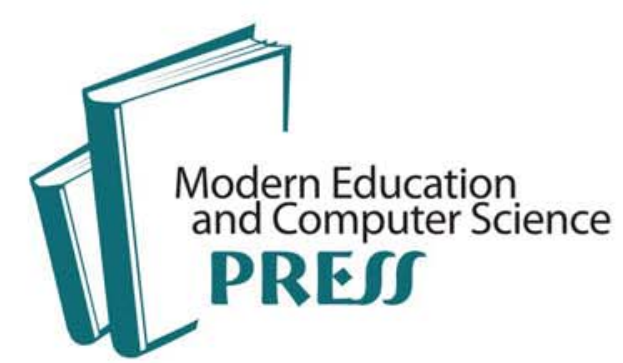




\section{International Journal of Image, Graphics and Signal Processing (IJIGSP)}

ISSN Print: 2074-9074, ISSN Online: 2074-9082

Volume 4, Number 5, June 2012

\section{Contents}

\section{REGULAR PAPERS}

A Review on Graph Based Segmentation

K. Santle Camilus, V. K. Govindan

Hybridization of DCT and SVD in the Implementation and Performance Analysis of Video Watermarking

Ashish M. Kothari, Ved Vyas Dwivedi

Stabilogram mPCA Decomposition and Effects Analysis of Several Entries on The Postural Stability

Dhouha MAATAR, Zied LACHIRI, Régis FOURNIER, Amine NAIT-ALI

A Geodesic Active Contour Level Set Method for Image Segmentation

K.R.Ananth, S.Pannirselvam

Efficient Global and Region Content Based Image Retrieval

Ibrahim S. I. Abuhaiba, Ruba A. A. Salamah

A Semantic Connected Coherence Scheme for Efficient Image Segmentation

P.Navaneetham, S.Pannirselvam

Intravascular Ultrasound Image Segmentation Using Morphological Snakes

Mrabti Mohamed Amine, Hamdi Mohamed Ali

Wavelet Based Some Julia Sets of Rational Maps Having Zhukovskii Function 